Revista Pax Domini é licenciada sob uma Licença Creative Commons.

\title{
A REPRESENTAÇÃO DO SAGRADO NO ROMANCE CHUVA BRANCA, DE PAULO JACOB
}

\author{
Jamescley Almeida de Souza ${ }^{1}$
}

\begin{abstract}
Resumo
Chuva branca, o mais famoso romance de Paulo Jacob, é uma porta de entrada para o encontro com a Amazônia e com a forma com que ela encara e vive a religião e o sagrado. Por meio de Luis Chato, o representante coletivo do homem deste espaço, o romance mostra que a Amazônia, em especial aquilo que no trabalho eu chamo de a "Terceira Amazônia", possui uma maneira peculiar de viver a sua religiosidade. Baseado no sincretismo religioso que veio a se formar a partir da religião cristã e da tradição indígena, o homem deste espaço clama por todos os santos, deuses e entidades mitológicas que podem Ihe auxiliar. O trabalho ressalta, ainda, o fato de o seu autor, Paulo Jacob, judeu e de tradição monoteísta, ter conseguido retratar, com realidade, esse aspecto da religiosidade amazônica.
\end{abstract}

Palavras-chave: Chuva branca; Sagrado; Terceira Amazônia; Sincretismo religioso.

\begin{abstract}
Chuva branca, the most famous novel written by Paulo Jacob, is one of the entrances for the meeting with the Amazon and with the way how its people see and live the religion and the sacred. Through Luis Chato, the collective representative of the man from this space, the novel shows that the Amazon, especially that the work calls as "Third Amazon" (Batista, 2007), has a particular way of living its religiosity. Based upon the religious syncretism that took place from the Christian religion and from the indigenous tradition, the man from this space begs all the saints, gods, and mythological entities which can help him. The work still emphasizes the fact of its author, Paulo Jacob, a Jew and monotheistic person, have had the triumph of representing, with reality, this aspect of the Amazonian religiosity.
\end{abstract}

Keywords: Chuva Branca; Sacred; Third Amazon; Religious syncretism.

\section{Introdução}

Sendo o mais famoso romance do escritor amazonense Paulo Jacob (1923-2003), Chuva branca é uma das portas de entrada para o conhecimento e para o encontro com

\footnotetext{
${ }^{1}$ Mestre em Letras da UFAM. Doutorando em Sociedade e Cultura na Amazônia (UFAM).
}

Revista Pax Domini | Faculdade Boas Novas | v. 3 | p. 117 - 142 | ago. 2018 
a sociedade e com a cultura da Terceira Amazônia ${ }^{2}$. Mitos, crendices, um conhecimento magnífico da floresta, traços da heurística indígena, além de "uma linguagem própria, peculiar à região, garimpada nas línguas dos povos autóctones"3 são alguns dos aspectos vistos no premiado romance do autor judeu-amazonida. Neste trabalho, em particular, o enfoque recairá sobre o sagrado 4 e sobre o aspecto religioso deste espaço que são veiculados pelo romance.

Como todo "texto literário ao mesmo tempo contesta e supõe uma cultura" ${ }^{5}$, Chuva branca é a vera-efígie da maneira com que esta Amazônia, chamada de "Terceira" por Djalma Batista costuma tratar e encarar a religião e o sagrado. Sabe-se que Paulo Jacob viveu e trabalhou durante dez anos "no interior do Estado do Amazonas, de onde retirou muito da realidade, do mito e do sincretismo religioso da Amazônia"6. Foi esta, pode-se dizer, a experiência que o auxiliou na representação deste aspecto. Como expressa Louro "a experiência da vida em Jacob é a grande responsável pela formação da narrativa, pois quem viaja e vive intensamente uma aventura, faz parte de uma grande revolução social, conforme o momento que atravessa na vida"7.

Chuva branca é um monólogo interior de um ribeirinho que se perde na floresta e tenta, a partir daí, encontrar o caminho de volta para casa. Por quarenta dias, ele, Luis Chato, passa perdido em meio à mata virgem, sentindo fome, sede, doente e quase nu. Já quase sem esperanças de encontrar o caminho de volta para a família, ele começa a fazer, como se verá mais adiante no texto, promessas para "Nossa Senhora, meu Cristo, meu Curupira, o diabo, o inferno", enfim, "todos os santos conhecidos" ${ }^{8}$. Quando ele

${ }^{2} \mathrm{O}$ espaço de Chuva branca é uma comunidade ribeirinha. Daí me utilizar, aqui, da classificação cunhada por Djalma Batista (2007, p. 114), estudioso que designa a Terceira Amazônia como sendo a "Amazônia rural", lugar onde estão inseridos os "habitantes das vilas, povoados, 'freguesias', aldeias, sítios, fazendas, seringais".

${ }^{3}$ LOURO, Francisca de Lourdes Souza; SOUZA, Jamescley Almeida. Chuva Branca: o retrato cultural da sociedade amazônica brasileira na obra de Paulo Jacob. Revista Decifrar, v. 02, p. 135-151, 2014, p. 136. ${ }^{4}$ Neste trabalho, utilizo-me do conceito de sagrado, tal como ele, é postulado por Rudolf Otto na obra $O$ sagrado (2007). Nas palavras deste autor, o sagrado não é o "atributo absolutamente moral, como perfeitamente bom", geralmente, usado como sinônimo de santidade no cristianismo" (OTTO, 2007, p. 37). 5 JOUVE, Vincent. A leitura. Trad. Brigitte Hervot. Editora UNESP: São Paulo, 2002, p. 137.

${ }^{6}$ SOUZA, Jamescley Almeida. Paulo Jacob: uma fortuna crítica. O Guari (União da Vitória), n. 1, v. 1, 2015.

${ }^{7}$ LOURO, Francisca de Lourdes Souza. A significação social na Amazônia no romance Chuva Branca de Paulo Jacob. Novum Millenium, Manaus, v. 5, p. 72-78, 2007.

${ }^{8}$ JACOB, 1968, pp. 231, 243.

Revista Pax Domini | Faculdade Boas Novas | v. 3 | p. 117 - 142 | ago. 2018 
percebe que não está sendo auxiliado por nenhum deles, uma vez que demora a atinar com o caminho que o levaria para casa, ele se desfaz das suas obrigações firmadas nas promessas e os insulta: "que merda, santo coisa nenhuma, só azar, desgraça, padecimento"'.

São precisamente, esses dois traços evidenciados no comportamento do narrador e protagonista Luis Chato - a invocação de todos os santos e "deuses" - que podem the valer na situação em que ele se encontra e a rapidez com que se desfaz das promessas feitas a eles, bem como os insultar - que permite a análise, no romance Chuva branca, de um sincretismo religioso e de uma maneira amazônica de ser e de viver a religião e o sagrado. Sobre essa última ideia, é importante lembrar que Galvão, quanto à vida religiosa, reconheceu um elemento "local" e "peculiar à Amazônia" que desempenha uma importante função "na estrutura dessa sociedade", imprimindo-lhe "um caráter regional" 10 .

Este artigo tem como objetivo tecer considerações em torno desses dois aspectos. Começo analisando o que chamo, aqui, de uma maneira amazônica de ser e de viver a religião e o sagrado, partindo, posteriormente, para realizar um olhar sobre o sincretismo religioso na Terceira Amazônia. Finalizo emitindo alguns comentários sobre como, sendo Paulo Jacob um judeu, de tradição monoteísta, portanto, absorveu e divulgou os aspectos religiosos que marcam a realidade social deste espaço.

\section{A maneira amazônica de viver a religião e o sagrado}

A narrativa sobre a vida de Luis Chato, no romance Chuva branca, revela muito da identidade amazônica de ser e de viver a religião e o sagrado. Um desses traços, que o leitor toma conhecimento tão logo entre em contato com o aspecto religioso veiculado pelo romance, é que reina nesta Amazônia, ao lado das formas conservadoras de

\footnotetext{
9 Op. cit., p. 175.

${ }^{10}$ GALVÃO, Eduardo. Santos e visagens: um estudo da vida religiosa de Itá, Baixo Amazonas. São Paulo: Companhia Editora Nacional, 1955, pp. 3, 4.
}

Revista Pax Domini | Faculdade Boas Novas | v. 3 | p. 117 - 142 | ago. 2018 
catolicismo, um grande catolicismo popular ${ }^{11}$. Como bem assevera Galvão "o caboclo de Itá [comunidade estudada por ele], como da Amazônia em geral, é católico"12.

Mesmo nas longínquas comunidades ribeirinhas, como é o caso daquela retratada em Chuva branca, é possível dizer que o catolicismo se faz presente, amalgamado, é claro, a outras crenças, práticas e tradições. Tal é o que podemos conferir, nestas palavras, por meio do monólogo de Luis Chato: "Depois domingo, data santificada, tinha mau sobrosso caçar neste dia [...]. Onde estou, minha Nossa Senhora! A noite baixando, preciso chegar"13. Esse excerto exemplifica, perfeitamente, o que Geertz quis dizer quando asseverou que "os símbolos sagrados funcionam para sintetizar o ethos ${ }^{14}$ de um povo [...] e sua visão de mundo"15. Dito de outro modo, conhece-se a crença de Luiz Chato por meio do que ele expressa aqui.

Neste trecho acima, momento em que Luis Chato já tem saído de casa para caçar, recorda-se o motivo pelo qual um de seus compadres não o acompanhou na caçada: era "domingo, data santificada". Esse comportamento, a guarda do domingo como um dia considerado santo, por ser o "dia do Senhor", alusão feita à ressurreição de Cristo, corrobora, ao lado do nome da santa por ele clamado, o fato constatado por Galvão de que "o caboclo [...], em geral, é católico"16.

Não seria excessivo afirmar que, assim, o é por causa da fé que foi determinada durante a colonização. À semelhança do que ocorreu no antigo Império Romano, quando "Constantino tomou o nome de Cristo por estandarte"17, adotando o cristianismo como a religião oficial do Império, no Brasil, e bem assim na Amazônia, a fé cristã foi uma imposição. Sobre esse assunto irei abordar com mais vagar no momento em que estiver tecendo comentários sobre esse sincretismo religioso que hoje se vê na Amazônia.

\footnotetext{
${ }^{11}$ Entende-se por catolicismo popular o "catolicismo praticado pelas pessoas que compõem o povo em geral, leigos ou até clérigos, em contraposição ao catolicismo oficial praticado pela Igreja enquanto instituição hierárquica" (TUVERI, 2013, p. 92).

12 GALVÃO, 1955, p. 3.

13 JACOB, 1968, pp. 12, 71.

${ }^{14}$ É a síntese dos costumes de um povo. Segundo Geertz (2008, p. 92), "é o tom, o caráter e a qualidade de sua vida, seu estilo moral e estético [...]. E o quadro que elabora das coisas como elas são na simples realidade, seu conceito da natureza, de si mesmo, da sociedade".

${ }^{15}$ GEERTZ, Clifford. A interpretação das culturas. Rio de Janeiro: LTC, 2008, p. 66.

${ }^{16}$ GALVÃO, 1955, p. 3.

17 GONZÁLEZ, Justo L. E até aos confins da Terra: uma história ilustrada do Cristianismo. Trad. Key Yuasa. São Paulo: Vida Nova, 1995, p. 1.
}

Revista Pax Domini | Faculdade Boas Novas | v. 3 | p. 117 - 142 | ago. 2018 
Mas o importante, todavia, é destacar, aqui, uma das razões dessa quantidade esmagadora da população se considerar católica: a fé católica foi imposta pelos colonizadores ${ }^{18}$. As ordens religiosas que atuaram na região, franciscanos, carmelitas, jesuítas e mercedários, foram uma "determinação da Coroa portuguesa" ${ }^{19}$. Como lembra Montesquieu "quando uma religião nasce [...] num Estado, ela acompanha normalmente o plano de governo onde foi estabelecida, pois os homens que a recebem e aqueles que fazem com que seja recebida não têm outras ideias sobre a ordem além daquelas do Estado no qual nasceram"20. E essa relação entre Estado e religião aparece de forma ainda mais íntima em Hegel o qual disse ser o Estado "a vontade divina como espírito presente ou atual que se desenvolve na formação e organização de um mundo"21.

Sendo uma fé imposta, praticantes de outros cultos que, a princípio, seriam incompatíveis com o catolicismo herdado dos colonizadores, também seriam católicos. Eles, na verdade, assim se consideram, tal como revelou Maués, ao realizar pesquisa sobre o "catolicismo e o xamanismo", por exemplo. Segundo o antropólogo, "para os pajés e para os praticantes da pajelança cabocla, de um modo geral, a mesma não é incompatível com o catolicismo. Os pajés e os adeptos desse culto consideram-se católicos"22. Em outra pesquisa o mesmo antropólogo acabou percebendo que não estavam erradas as pessoas ao se declararem católicos, sem mencionar suas práticas xamânicas, já que estas, na verdade, estão incorporadas às crenças e práticas do catolicismo popular que praticam.

Veríssimo, por sua vez, emite uma crítica a esse catolicismo ao dizer que "apesar de a grande maioria dos amazônidas se declararem católicos, católicos o são apenas no nome e por se haverem batizado"23.

\footnotetext{
${ }^{18}$ BATISTA, Djalma. O complexo da Amazônia: análise do processo de desenvolvimento. 2 ed. Manaus: Editora Valer, Edua e Inpa, 2007, p. 55.

19 SANTOS, Francisco Jorge dos. História do Amazonas: 1 série, ensino médio. Rio de Janeiro: MEMVAVMEM, 2010, p. 80.

20 MONTESQUIEU, Charles de Secondat, Baron de. 0 espírito das leis. Trad. Cristina Murachco. São Paulo: Martins Fontes, 1996, p.469.

${ }^{21}$ HEGEL, Georg Wilhelme Friedrich. Princípios da filosofia do direito. Trad. Orlando Vitorino. São Paulo: Martins Fontes, 1997, p. 233.

22 MAUÉS, Raymundo Heraldo. Catolicismo e xamanismo: comparação entre a cura no Movimento Carismático e na pajelança rural amazônica. ILHA - Florianópolis, v.4, n.2, dezembro de 2002, p. 53.

${ }^{23}$ VERÍSSIMO, José. Estudos Amazônicos. Belém: Universidade Federal do Pará, 1970, p. 54.
}

Revista Pax Domini | Faculdade Boas Novas | v. 3 | p. 117 - 142 | ago. 2018 
Utilizo-me do excerto abaixo, o qual dialoga com o que foi dito acima por Veríssimo, para realizar uma discussão sobre a religiosidade do homem amazônico e a forma como ele encara o sagrado. De acordo com o que disse Araújo, na Amazônia "a religião se desenvolveu ao modo da largueza do meio geográfico"24. É esta "largueza" religiosa que passará a ser analisada a seguir.

O quarto aquela alegria, um gasto danado. Tem gente desabusada que até reclama. Diz ai ao parente do morto que está faltando cachaça [grifos meus]. A que tinha acabou. O defunto, muito bem deitadão, não quer saber do prejuízo que deu. No baralho, dominó, ai velação inteira. Arengam, gargalhada não falta. Uma pouca vergonha até no terreiro, com as cunhatãs. Naquela animação de sereno de festa. Correu noticia de morte, começa a avacalhação. Tem velação na casa desse ou daquele, parece que vai ser animada. Aquela zinha furada de pouco, do causo que acabou na polícia, me disse que vai sozinha. Xiri solto, sem pai por perto. Solta o que é dela, mulher beneficiada não tem perigo ${ }^{25}$.

Neste particular, após observar pelo excerto acima a forma com que os membros pertencentes à comunidade de Luis Chato se comportam em um velório, é bom destacar o que disse Sérgio Buarque de Holanda sobre os brasileiros e os ritos:

nós nos comportamos de modo perfeitamente contrário à atitude já assinalada entre japoneses, onde o ritualismo invade o terreno da conduta social para darIhe mais rigor. No Brasil é precisamente o rigorismo do rito que se afrouxa e se humaniza ${ }^{26}$.

Dito de outra maneira, ao contrário do povo oriental em questão, o brasileiro, em geral, não é dado a seguir ritos ou cerimônias. Tudo, ou quase tudo, para ele, passa por essa frouxidão.

O narrador de Chuva branca recorda, aqui, o episódio de um funeral ocorrido em sua comunidade. E, como é possível perceber, mais do que a consternação que poderiam sentir com relação ao morto ou com a família deste, os participantes do velório estão mais preocupados com a "cachaça" que está faltando. Vê-se que o que eles demonstram é menos um comportamento de profunda seriedade diante do féretro ou de

24 ARAÚJO, André Vidal de. Introdução à Sociologia da Amazônia. 2 ed. revista. Manaus: Editora Valer/Governo do Estado do Amazonas/Editora da Universidade Federal do Amazonas, 2003, p. 463. 25 JACOB, 1968, p. 31.

${ }^{26}$ HOLANDA, Sérgio Buarque de. Raízes do Brasil. 26 ed. São Paulo: Companhia das Letras, 1995, p. 149.

Revista Pax Domini | Faculdade Boas Novas | v. 3 | p. 117 - 142 | ago. 2018 
apoio à família órfã do que uma oportunidade para regalarem-se e se entregarem aos prazeres humanos, como a bebida, neste caso. O sagrado, aqui, em seu aspecto de mysterium $^{27}$, no sentido de "estranho" e de "não-compreendido"28, e que se materializa pela presença da morte diante de seus olhos, não chega a exercer neles nenhum poder coercitivo. O que disse Geertz, a saber, que "o sagrado contém em si mesmo um sentido de obrigação intrínseca: ele não apenas encoraja a devoção como a exige" 29 , não encontra, aqui, qualquer resposta ou reação. Ou, ainda, para citar Platão, não há coadunação entre o ser humano e o sagrado que se faz presente, pois como disse este, "estando o filósofo em contato com o que é sagrado e sujeito à ordem, ele mesmo tornase ordenado e sagrado, dentro do limite permitido pela natureza humana ${ }^{30 "}$.

Conexa à bebida, percebe-se a presença de jogos, como o "dominó" e o "baralho", de "gargalhadas" e até de "pouca vergonha". Como revela o narrador, a "notícia de morte" que corre pelos terreiros avisando sobre a "velação", é motivo para que entre em cena a "avacalhação". O velório é animado com a presença de "cunhantãs" e de "mulher beneficiada" com as quais os veladores esperam ter alguma aventura sexual. Ao invés de suscitar o pesar profundo, afloram-se, no velório, as sexualidades.

Destaco, especificamente, a forma como se referem ao defunto: "o defunto, muito bem deitadão, não quer saber do prejuízo que deu". Esse discurso, além de evidenciar uma certa ausência de consideração para com o féretro, traz à luz uma importante tônica da realidade social dessa Amazônia: a miséria. Um velório, momento em que se recepcionam aqueles que vêm ajudar a família órfã a dividir a dor sentida, acaba economicamente pesado para esta.

Ainda nessa linha, não poderia deixar de mencionar, pela sua importância na religiosidade desse homem amazônico, o que poderia ser chamada de mistura entre sagrado e profano, visualizada na maneira como Luis Chato menciona o nome de Deus

\footnotetext{
${ }^{27}$ Para Otto (2007, p. 59), o mysterium é um aspecto do numinoso (sagrado) que é "inapreensível não só porque minha apercepção do mesmo tem certas limitações incontornáveis, mas porque me deparo com algo 'totalmente diferente"'.

${ }^{28}$ OTTO, Rudolf. O sagrado: os aspectos irracionais na noção do divino e sua relação com o racional. 3 ed. Trad. Walter O. Schlupp. São Leopoldo: Sinodal/EST; Petrópolis: Vozes, 2007, p. 58.

${ }^{29}$ GEERTZ, 2008, p. 92.

30 PLATÃO. A República. Trad. Enrico Corvisieri. São Paulo: Editora Nova Cultural, p. 249.
}

Revista Pax Domini | Faculdade Boas Novas | v. 3 | p. 117 - 142 | ago. 2018 
no mesmo contexto em que chama o que é conhecido como palavrões ${ }^{31}$. Como no caso em que topa, na mata, com uma cobra surucucu: "Égua! Minha Nossa Senhora, não saltasse ligeiro [...], palmo em cima da focinheira da surucucu"32. Ou mesmo neste outro, quando dá uma topada:

Puta merda! Deus te salve. Falam que é lembrança de alma, quer missa, salvação, quando se leva topada. Com essa história, o dedão arrombado, a gente tem que chamar é nome [grifos meus], se esquece de Deus te salva. Sei lá se morreu pagão, quem mandou não se batizar. E eu é que vá pagar pelos pecados dos outros. Ainda por cima perder a inambu ${ }^{33}$.

O que é observado, nestas palavras do ribeirinho, é a maneira como ele justapõe, ou mesmo combina, o que é dito palavrão, "égua" e "puta merda", ao nome de "Deus" e de "Nossa Senhora", principalmente levando-se em consideração o que reza o segundo mandamento da doutrina católica: "não tomar o seu santo nome em vão". Aqui não estou interessado em tecer considerações de cunho especificamente doutrinário ou moral que identificam e fazem parte do catecismo católico. Mas apontar, por outro lado, a presença, no mesmo contexto, da atitude religiosa de lembrar ou clamar pela divindade em situações de necessidades e a "paixão" do fiel que, segundo Maués "é o elemento essencial do catolicismo popular brasileiro" ${ }^{34}$.

À luz da tradição judaico-cristã - pois, cum grano salis, assim de pode considerar a sociedade e a cultura existentes na Amazônia - é certo dizer que o nome de uma divindade é um de seus aspectos mais sagrados, pois o nome, como lembra Ratzinger atinge "a própria coisa35". Os judeus, por exemplo, tinham o nome de Deus, Yahweh, por tão sagrado para ser pronunciado que o "substituem pela palavra Adonai, 'meu

${ }^{31}$ A doutrina cristã desencoraja, nas cartas paulinas, o uso de palavrões por parte de seus fiéis, como pode ser visto na Carta aos Efésios: "Não saia da vossa boca nenhuma palavra torpe, mas só a que for boa para promover a edificação, para que dê graça aos que a ouvem" (Ef. 4.29).

32 JACOB, 1968, p. 109.

33 JACOB, 1968, p. 33.

${ }^{34}$ MAUÉS, Raymundo Heraldo. A Mãe e o Filho como peregrinos: dois modelos de peregrinação católica no Brasil. Religião e Sociedade, Rio de Janeiro, 33(2): 121-140, 2013, p. 124.

35 RATZINGER, Joseph. Introdução ao cristianismo: preleções sobre o símbolo apostólico. Trad. Pe. José Wisniewski Filho. São Paulo: Editora Herder, 1970, p. 56.

Revista Pax Domini | Faculdade Boas Novas | v. 3 | p. 117 - 142 | ago. 2018 
Senhor"'36. Não é à toa que a verdadeira pronuncia, acredita-se, teria sido perdida ao longo do tempo.

$\mathrm{Na}$ tradição islâmica, por sua vez, o só mencionar o nome de Deus é motivo de estremecimento, como registra o versículo 2 da $8^{\text {a }}$ surata do Alcorão: "só são fiéis aqueles cujos corações, quando Ihes é mencionado o nome de Deus estremecem"37. Em Linguagem e mito, Cassirer ressalta que o nome de um deus está tão, estreitamente, ligado à sua essência, nas suas palavras, para o "domínio para o qual foi, na sua origem, criado", que uma alteração que faça esse nome perder "sua conexão com o tesouro vivo da linguagem" também pode causar alteração na consciência de sagrado que ele seria capaz de despertar ${ }^{38}$.

Segundo, ainda, Ratzinger, a declaração de Cristo "manifestei o teu nome aos homens do mundo que deste", que está no evangelho de João, deve ser interpretada como sendo o próprio Cristo: "a ideia do nome entra agora em uma fase nova e decisiva. Aqui 'nome' não é mais somente uma palavra, mas uma pessoa: o próprio Cristo"39.

Em sua pesquisa intitulada Nomes secretos e riqueza visível: nominação no noroeste amazônico, Hugh-Jones descobriu existir, entre os Tukano, "etnônimos" de cunho "sagrado" e "semi-sagrados", demonstrando que a língua pode funcionar como "uma manifestação da essência, do espírito e da potência do grupo 40". Todavia, o que parece realmente sobressair, aqui, é o caráter sagrado que pode estar atrelado à um nome.

O que notamos, entretanto, no comportamento do protagonista de Chuva branca é o que, em sua pesquisa intitulada $A$ Mãe e o Filho como peregrinos, Maués denominou de "aspecto lúdico do catolicismo popular brasileiro" ${ }^{11}$. Que não exclui, por certo, a devoção, mas também. se recusa a se entregar à ascese. E nesse "aspecto lúdico", para o qual

\footnotetext{
${ }^{36}$ LIVINGSTONE, George Herbert et al. Comentário bíblico Beacon: Gênesis a Deuteronômio. Trad. Luís Aron de Macedo. Rio de Janeiro: CPAD, 2005, p. 433.

37 ALCORÃO. Português. Alcorão. Trad. Mansour Challita. Rio de Janeiro: Associação Cultural Internacional Gibran, 1995.

${ }^{38}$ CASSIRER, Ernst. Linguagem e mito. 3 ed. Trad. J. Guinsburg e Míriam Schnaiderman. São Paulo: Perspectiva, p. 36)

${ }^{39}$ RATZINGER, Joseph. Introdução ao cristianismo: preleções sobre o símbolo apostólico. Trad. Pe. José Wisniewski Filho. São Paulo: Editora Herder, 1970, p. 55.

${ }^{40} \mathrm{HUGH}-J O N E S$, Stephen. Nomes secretos e riqueza visível: nominação no noroeste Amazônico. Mana, vol.8, no. 2, Rio de Janeiro, Oct. 2002, p. 4.

${ }^{41}$ MAUÉS, Raymundo Heraldo. A Mãe e o Filho como peregrinos: dois modelos de peregrinação católica no Brasil. Religião e Sociedade, Rio de Janeiro, 33(2): 121-140, 2013, p. 124.
}

Revista Pax Domini | Faculdade Boas Novas | v. 3 | p. 117 - 142 | ago. 2018 
chama atenção o antropólogo paraense, os xingamentos figuram de maneira importante, como revelam as palavras de Luis Chato: "a gente tem que chamar é nome". Maués observou comportamento semelhante ao do ribeirinho ao acompanhar, em sua pesquisa, o peregrino Chico em uma romaria:

Além disso, a maneira como Chico carregava a cruz, muitas vezes, não indicava maior devoção. Em momentos de dificuldades, chegava mesmo a xingá-la com palavrões [grifos meus]. Uma "pinga" (cachaça) podia ser bem-vinda, a despeito de nosso trato de evitar bebidas alcoólicas. Nenhuma mulher, que eu saiba, "abriu as pernas" para Chico, durante a romaria, mas ele não deixou de dirigir galanteios a algumas, mesmo estando com a cruz nos ombros [...] Atenção para o aspecto lúdico do catolicismo popular brasileiro, que não deixa de lado seu jeitinho, sua malandragem (em oposição ao "caxias"), como nos diz Da Matta (1983), mas também não exclui o sofrimento e a devoção. Essa é uma característica que não se perdeu nesse catolicismo tradicional de fontes ibéricas medievais, que vem desde a Colônia, a despeito das tentativas disciplinadoras dos agentes da "romanização", os quais, desde o final do XIX, tentaram dar caráter mais europeu a suas práticas no Brasil"2.

O mesmo tipo de "comportamento folgazão" é visto por Maués, ao participar de uma festa de santo no interior do município de Vigia:

'Viva Santo Antônio!', 'Viva o pau do santo!' (referindo-se ao mastro). O povo que acompanhava o cortejo conversava animadamente, rindo muito das brincadeiras que eram feitas pelos que carregavam o mastro. As únicas pessoas sérias, em todo o percurso, eram o juiz e a juíza da festa. Num dado momento, a música deixou de tocar e o cortejo foi momentaneamente interrompido, porque os músicos pararam para comer fruta de cedro que havia pelo caminho. A música só voltou depois de muitos impropérios dirigidos aos músicos pelos carregadores do mastro ${ }^{43}$.

Em outras palavras, o comportamento mostrado por Luis Chato, ao misturar sagrado e profano por meio de seus xingamentos, se entrosa exatamente com o que Maués chamou de "aspecto lúdico", o qual se revela como um dos traços mais típicos do assim chamado catolicismo popular brasileiro.

Passo agora a fazer, por meio dos excertos colocados abaixo, algumas considerações a respeito das promessas perpetradas por Luis Chato aos santos e aos padroeiros dos quais ele se vale na tentativa de encontrar o caminho de volta para casa.

\footnotetext{
42 MAUÉS, 2013, p. 124.

${ }^{43}$ MAUÉS, Raymundo Heraldo. Os santos e o catolicismo popular. Norte Ciência, vol. 2, n. 1, p. 126, 2011 , p. 5.
}

Revista Pax Domini | Faculdade Boas Novas | v. 3 | p. 117 - 142 | ago. 2018 
Destaco especificamente a superficialidade das promessas de consagração efetuadas por ele comprovadas diante da maneira instantânea com que ele se desfaz delas e termina em xingamentos aos seus mediadores. Por fim, concluo o tópico desenvolvendo uma discussão sobre a temática do sacrifício, tal como o ribeirinho promete aos santos, para cuja discussão eu trago as contribuições realizadas por Mauss e Hubert sobre o assunto ${ }^{44}$.

\begin{abstract}
Saindo, pago promessa a São Francisco, acompanho procissão segurando a Pomba-do-Divino [...]. Acompanhar procissão com um toro de itaúba na cabeça, dos grandes que tenha peso. Sacrifício que dou aos santos, milagre de encontrar o caminho de casa [...]. Que merda, santo coisa nenhuma, só azar, desgraça chamando desgraça, padecimento. Desvalido de tudo, da devoção no padroeiro coisa alguma valer. Dor miserável, num desproposito desse de homem gemer dessa forma [...]. Dessa desgraceira, proteção de santo nenhum, até o padroeiro, milagroso lá das nossas bandas, desesquecido do tão devoto dele. De nunca não faltar aos festejos lá das alegrias dele. Galinha sabe querer para o leilão, botar arrematação maior. Dinheiro pra capela, vela pra alumiação do altar, ajoelhado de fazer é horas no terço, dar o pago dessa forma. Vá pro inferno tamanho dos sacrifícios, só ver ingratidão, santo desconhecido ${ }^{45}$.
\end{abstract}

Começo destacando a promessa realizada por Luis Chato "a São Francisco", no intuito de "encontrar o caminho de casa", fato que traz a lume um importante aspecto do catolicismo popular brasileiro na Amazônia. A sincretização da pajelança com os batuques e bem assim com as superstições formam, ao lado dos Santos de devoção, "o sistema de religião da Amazônia" ${ }^{46}$. Em Chuva branca, o santo católico que surge nomeado é São Francisco de Assis, considerado o padroeiro das pessoas carentes, dos animais e da ecologia. Aparecem, igualmente, "São Bento [...], bom santo de acertar da primeira" 47 , invocado pelo ribeirinho durante os tiros nas caçadas, e também "São Brás"48, clamado em caso de engasgo por espinha. Note-se que, em relação a São Francisco, as causas que são objetos de proteção por parte do santo se entrosam perfeitamente com uma das tônicas sociais que marcam essa Amazônia — a miséria -

\footnotetext{
${ }^{44}$ MAUSS, Marcel; HUBERT, Henri. Sobre o sacrifício. São Paulo: Cosac Naify, 2005.

45 JACOB, 1968, pp. 89, 175, 250.

${ }^{46}$ ARAÚJO, 2003, p. 463.

47 JACOB, 1968, p. 211.

${ }^{48}$ Op. cit., p. 224.
}

Revista Pax Domini | Faculdade Boas Novas | v. 3 | p. 117 - 142 | ago. 2018 
e com aquilo pelo qual ela é geralmente conhecida e evocada em outras partes do Brasil e no exterior: a natureza.

Tomando algumas das ideias de Galvão em Santos e visagens, deve-se ressaltar que a "devoção aos Santos padroeiros da localidade e a um pequeno número de 'santos de devoção" constituem o "catolicismo do caboclo amazônico" 49 . Segundo Holanda, em Raízes do Brasil, essa forma de culto tem antecedentes na península Ibérica e na Europa medieval, se expressando na vontade em que "cada casa quer ter sua capela própria, onde os moradores se ajoelham ante o padroeiro e protetor [...]. Todos, fidalgos e plebeus, querem estar em intimidade com as sagradas criaturas e o próprio Deus é um amigo familiar, doméstico e próximo"50. Parafraseando o pensamento de Holanda, o traço mais específico do espírito brasileiro, o "homem cordial", espraia-se também, ou até mais ainda, para o domínio religioso.

Organizadas com base no pequeno grupo local, essas devoções encontram sua "expressão de maneira mais enfática no momento da festa" 51 . Essas festas geralmente se organizam sob a forma de folias, de folguedos, de festejos, de romarias, de procissões, assim como, sob outros tipos de rituais. Elas são o momento sublime de congraçamento e de celebração ou, para citar Durkheim, uma espécie de corrobori ${ }^{52}$ do homem amazônico, resultando num "sentimento de pertencimento", pois "a festa é a própria sociedade que está sendo comemorada e refeita" 53 .

Em Chuva branca, vemos o seu narrador mencionar os "festejos", o "padroeiro", o "leilão" das prendas doadas ao santo para o sustento do santuário, assim como o costume de "botar arrematação", práticas comumente observadas nestas festas

49 GALVÃO, 1955, p. 04.

50 HOLANDA, 1995, p. 149.

${ }^{51}$ MAUÉS, 2011, p. 8.

52 Nome dado, em etnografia, às assembleias ou cerimônias religiosas observadas nas sociedades australianas. É uma fase da vida dessa população que se contrasta com a fase em que ela "encontra-se dispersa em pequenos grupos que cuidam dos seus afazeres, independente uns dos outros" (DURKHEIM, 2003, p. 63).

${ }^{53}$ MENEZES, Renata de Castro. Celebrando São Besso ou o que Robert Hertz e a Escola Francesa de Sociologia têm a nos dizer sobre festas, rituais e simbolismo. Religião e Sociedade, Rio de Janeiro, 29(1): 2009, p. 183.

Revista Pax Domini | Faculdade Boas Novas | v. 3 | p. 117 - 142 | ago. 2018 
populares. Geralmente cada local possui seu santo padroeiro e os festejos são as festas "mais importantes", realizadas "em honra dos santos locais, padroeiros ou de devoção" 54 .

Destaco, a partir do comportamento de Luis Chato em falar mal do santo de devoção que não o socorre, o que chamo, aqui, de caráter superficial de suas promessas outrora feitas. Em um momento, ele está a dizer "saindo, pago promessa a São Francisco" ou "acompanho procissão segurando a Pomba-do-Divino". No outro, porém, a vociferar "que merda, santo coisa nenhuma, só azar [...]. Vá pro inferno tamanho dos sacrifícios, só ver ingratidão, santo desconhecido"55. Como observa Louro e Souza em trabalho que fizeram sobre Chuva branca, "com a mesma facilidade com que se apega às suas crenças, o homem amazônico também as lança para trás. Se Luis Chato está perdido na floresta e clama por tudo o que lhe vem à memória, mas estes não vêm em seu socorro, ele os insulta sem nenhum tipo de ressentimento"56. Esse caráter de superficialidade, ou "religiosidade de superfície", como será discutido abaixo, é um dos traços da devoção do caboclo amazônico, cujas raízes podem ser encontradas em uma maneira de ser mais geral: a brasileira ${ }^{57}$.

De acordo com Holanda o nosso culto se caracteriza por ser "sem obrigações e sem rigor, intimista e familiar, a que se poderia chamar, com alguma impropriedade, 'democrático'. Um culto que dispensava no fiel todo esforço, toda diligência, toda tirania sobre si mesmo, o que corrompeu, pela base, o nosso sentimento religioso" 58 .

Como foi citado acima no texto, as raízes desse sistema religioso podem ser encontradas, cum grano salis, na península lbérica, mas possuem, igualmente, DNA indígena, tomando-se em consideração que o brasileiro é o resultado da mistura das três raças. Pois, como constatou Eliade, mesmo o "homem arreligioso descende do homo religiosus e, queira ou não, é também obra deste, constituiu-se a partir das situações assumidas por seus antepassados" 59 .

\footnotetext{
54 GALVÃO, 1955, p. 68, 69.

55 JACOB, 1968, p. 250.

${ }^{56}$ LOURO; SOUZA, 2014, p. 144.

${ }^{57}$ HOLANDA, 1995, p. 150.

58 HOLANDA, 1995, p. 150.

${ }^{59}$ ELIADE, Mircea. Mito e realidade. Trad. Pola Civelli. São Paulo: Editora Perspectiva, 1972, p. 98.
}

Revista Pax Domini | Faculdade Boas Novas | v. 3 | p. 117 - 142 | ago. 2018 
Em Informação do Brasil e de suas capitanias, o padre Anchieta diz, sobre os indígenas, que "nenhuma criatura adoram por Deus, somente os trovões cuidam que são Deus, mas nem por isso lhes fazem honra alguma" ${ }^{0}$. Semelhantemente, Veríssimo registrou, na obra Estudos amazônicos, que

O índio e o selvagem lembravam-se da divindade unicamente por um sentimento interesseiro, sem que depois, quando já se julgava servido, Ihe agradasse qualquer sentimento de culto, respeito ou gratidão [grifos meus]. O mesmo se dá hoje com o tapuio e o mameluco, e aqueles mestiços em quem vieram a influir. O tajapurá, que ao partir para a pesca, levam plantado em um cestinho, amarrado à proa, acreditando seguramente que dele depende a boa pescaria, desde que voltam para a casa, com a canoa vazia ou cheia de peixe, é posto de parte, atirado sem nenhum, não direi respeito, mas cuidado ${ }^{61}$.

O homem amazônico, elemento resultante dessa matriz cultural (índio, europeu, em especial), manifesta o mesmo traço de religiosidade, conforme pode se verificar, aqui, pelo comportamento demonstrado por Luis Chato. Ainda na ordem do que foi dito acima, Holanda fala de um costume característico de "nosso velho catolicismo" que se resume em permitir "tratar os santos com uma intimidade quase desrespeitosa e que deve parecer estranho às almas verdadeiramente religiosas" 62 .

Na pesquisa em que relata um ritual a Santo Antônio, e do qual também participou, Maués observou o "comportamento folgazão" das pessoas que carregavam o mastro do santo. À medida que ia seguindo o cortejo, os que carregavam o mastro (um símbolo fálico) iam "bebendo cachaça, soltando impropérios e dando vivas ao santo, ao mesmo tempo em que realizam uma espécie de dança que simula, nos movimentos executados com o mastro ("pau" do santo), um ato sexual" 63 . Nessa linha se encontra, ainda, a forma como a religiosidade brasileira, de modo geral, costuma tratar "nosso Menino Jesus, companheiro de brinquedo das crianças e que faz pensar menos no Jesus dos evangelhos canônicos do que no de certos apócrifos, principalmente as diversas redações do Evangelho da Infância"64.

\footnotetext{
${ }^{60}$ BOSI, Alfredo. Dialética da colonização. São Paulo: Companhia das Letras, 1992, p. 67.

61 VERÍSSIMO, 1970, p. 61.

62 HOLANDA, 1995, p. 149.

63 MAUÉS, 2011, p. 7.

${ }^{64}$ HOLANDA, 1995, p. 149.
}

Revista Pax Domini | Faculdade Boas Novas | v. 3 | p. 117 - 142 | ago. 2018 
Uma última reflexão deve ser feita, aqui, antes de encerrar esse ponto e passar a abordar sobre o sacrifício. É sobre o que Bataille chama de "sentimento do sagrado" 65 e Otto de "sentimento de criatura" 66 , este último conceito sendo um aspecto do sagrado. $O$ que esse conceito quer dizer é que

O homem, no sentimento do sagrado, experimenta uma espécie de horror impotente. Esse horror é ambíguo. Sem dúvida alguma, o que é sagrado atrai e possui um valor incomparável, mas no mesmo instante isso parece vertiginosamente perigoso para esse mundo claro e profano onde a humanidade situa seu domínio privilegiado ${ }^{67}$.

Ou, nas palavras de Otto, isso seria "o sentimento da criatura que afunda e desvanece em sua nulidade perante o que está acima de toda criatura". Em outras palavras, estar diante do sagrado - "numinoso" nas palavras de Otto - provoca, na psique do homem, um reflexo que o leva à autopercepção da sua "própria condição peculiar", da sua dependência ${ }^{68}$. A mesma ideia aparece em David Hume, em seus Diálogos sobre a religião natural, embora não sob o conceito apresentado por Otto, como podemos observar:

Os mais religiosos e devotos de todos os filósofos pagãos foram, como você sabe, os antigos platônicos; não obstante, muitos deles, em particular Plotino, declararam, expressamente, que não se deve atribuir intelecto ou entendimento à Divindade, e que a maneira mais perfeita que temos de adorá-la consiste nãos em atos de veneração, reverência, gratidão ou amor, mas em uma espécie misteriosa de autoaniquilação ou extinção total de toas as nossas faculdades. São ideias algo exageradas, talvez; mas é forçoso reconhecer que, ao representarmos a Divindade como sendo tão inteligível e compreensível, e tão similar à mente humana, nos tornamos culpados da mais grosseira e tacanha parcialidade e nos arvoramos em modelo de todo o Universo ${ }^{69}$.

${ }^{65}$ BATAILLE, Georges. Teoria da religião. Trad. Sérgio Goes de Paula e Viviane de Lamare. São Paulo: Ática, 1993.

${ }^{66}$ OTTO, Rudolf. O sagrado: os aspectos irracionais na noção do divino e sua relação com o racional. 3 ed. Trad. Walter O. Schlupp. São Leopoldo: Sinodal/EST; Petrópolis: Vozes, 2007.

67 BATAILLE, 1993, pp. 18, 19.

68 OTTO, 2007, p. 41.

69 HUME, David. Diálogos sobre a religião natural. Trad. José Oscar de Almeida Outra Amazônia Marques. São Paulo: Martins Fontes, 1992, p. 53.

Revista Pax Domini | Faculdade Boas Novas | v. 3 | p. 117 - 142 | ago. 2018 
Pra concluir meu pensamento, devo dizer que a forma com que estes conceitos, tanto o de Bataille quanto o de Otto, se relacionam com este trabalho fica clara à luz do que Maués chamou de "comportamento folgazão" e "aspecto lúdico do Catolicismo popular brasileiro". Aqui não estou interessado, é claro, em elencar distinções entre catolicismo e protestantismo ou mesmo tecer considerações de cunho moral. Todavia, é certo que as manifestações que marcam o catolicismo popular brasileiro são "esperadas como parte dos festejos do santo, assim como as rezas, as ladainhas, as missas, as procissões, o arraial, a festa dançante, as brigas, os namoros e tudo o mais que compõe uma verdadeira festa de santo"70.

"Para o devoto popular", na verdade, "é difícil ver de forma separada as missas, rezas, ladainhas e procissões, das festas de barracões, dos arraiais e dos festejos que acontecem em torno dos mastros do santo que se festeja"71. Fica claro, portanto, que resta a questão se existiria, nesta religiosidade, espaço para o sentimento de "horror impotente", de desvanecimento, de pavor e de "nulidade" de que falam esses autores que foram trazidos para o diálogo (?). Ou, ainda, para o "saber filosófico sobre o sentido do mundo e da vida" ou o "poder ético ou mágico sobre si próprio ou sobre os outros" que, segundo Weber, marcam algumas das religiões e soteriologias da Ásia, em especial, da China ${ }^{72}$.

Sobre o sacrifício a São Francisco, Luis Chato promete fazê-lo seguindo em "procissão segurando a Pomba-do-Divino", mas principalmente com um "toro de itaúba na cabeça, dos grandes que tenha peso, sacrifício que dou aos santos"73. Esse excerto traz a lume importante contribuição de Mauss e Hubert a respeito do caráter do sacrifício ${ }^{74}$.

A partir do pensamento de Mauss e Hubert o sacrifício pode ser entendido como uma espécie de troca ou uma forma de "contrato". Neste particular, um contrato entre agentes humanos e sobrenaturais. Nessa linha do pensamento de Mauss e Hubert, Galvão

\footnotetext{
${ }^{70}$ MAUÉS, 2011, p. 7.

${ }^{71}$ PANTOJA, Vanda. Santos e Espírito Santo, ou católicos e evangélicos na Amazônia Marajoara. Tese (Doutorado) - Universidade Federal do Pará. Instituto de Filosofia e Ciências Humanas, Programa de Pós-Graduação em Ciências Sociais, Belém, 2011, p. 115.

${ }^{72}$ WEBER, Max. Sociologia. 7 ed. São Paulo: Ática, 2003, p. 143.

73 JACOB, 1968, p. 89.

${ }^{74}$ MAUSS; HUBERT, 2005.
}

Revista Pax Domini | Faculdade Boas Novas | v. 3 | p. 117 - 142 | ago. 2018 
também observou que "a relação entre o indivíduo e o santo baseia-se num contrato mútuo, a promessa ${ }^{75}$. Cumprindo aquele sua parte do contrato, o santo fará o mesmo. Promessas 'são pagas' adiantadamente para se obrigar o santo a retribuir sob a forma do benefício pedido".

Em Chuva branca, de um lado temos a parte humana, Luis Chato, e de outro, a sobrenatural, São Francisco. O contrato: o socorro dado ao ribeirinho da busca por encontrar o caminho de casa o levaria a participar de uma procissão por meio do sofrimento. De um lado está a dádiva, do outro, à obrigação. "Sacrificar é doar", como diz Bataille ${ }^{76}$. É precisamente em direção a esse duplo aspecto do sacrifício que chamam atenção Mauss e Hubert:

Se o sacrificante dá algo de si, ele não se dá: reserva-se prudentemente. Se ele dá, é em parte para receber. O sacrifício se apresenta sob um duplo aspecto. É um ato útil e uma obrigação. O desprendimento mistura-se ao interesse. Eis porque ele foi frequentemente concebido sob forma de um contrato ${ }^{77}$.

À guisa de uma última reflexão sobre esse tópico, compartilho com Maués o pensamento de que o sacrifício nem sempre implica no sofrimento. Mas, neste caso, o de Luis Chato, o sofrimento está presente. Seguir a procissão, carregar "um toro de itaúba cabeça" ou, como afirma em outro ponto, "carregar um eguaço toro de pau na procissão"78, tal como promete o ribeirinho, implica em um enorme esforço físico. Ocorre, aqui, a doação do corpo à divindade, geralmente sob à custa de muito sofrimento, como costuma ocorrer nessas peregrinações. É comum se ouvir falar nas "manhas, mazelas e triunfos de um sacerdote particular"79.

\section{Um olhar sobre o sincretismo religioso na Terceira Amazônia}

\footnotetext{
${ }^{75}$ GALVÃO, 1955, p. 42.

${ }^{76}$ BATAILLE, 1993, p. 24.

77 RIGONI, Ana Carolina Capellini. Os usos do corpo: dos sacrifícios 'primitivos' às religiões atuais. Revista da Faculdade de Educação Física da UNICAMP, no 1: 86-96, 2008, p. 91.

78 JACOB, 1968, p. 228.

${ }^{79}$ MAUÉS, 2013, p. 123.
}

Revista Pax Domini | Faculdade Boas Novas | v. 3 | p. 117 - 142 | ago. 2018 
Um aspecto do sistema religioso da Amazônia que se pode notar com clareza nas palavras do narrador de Chuva branca é o sincretismo de crenças. Perdido na floresta, Luis Chato revela esse aspecto da sua religiosidade ao clamar por todos, deuses, demônios e entidades míticas que pudessem auxiliá-lo: "Nossa Senhora, meu Cristo, meu Curupira, o diabo, o inferno, me carregue pra perto, ilharga do lugar onde moro. Amaldiçoada chuva branca, aquela anta era o tinhoso" 80 . Como pontuaram Louro e Souza "o que parece é que ele acredita em tudo e passa a clamar por qualquer um que possa lhe ajudar a mitigar as dores da sua vivência" 81 . Essa prática de o "indivíduo e a comunidade" apelarem para outras crenças, "reunidas àquelas cristãs", forma, segundo Galvão "o todo da religião" na Amazônia82.

Antes de dar prosseguimento à discussão do excerto acima, destacando como Luis Chato apela para todas as forças sobrenaturais, assim como para a mistura entre sagrado e profano que se faz a partir daí, ou ainda para o processo de formação sincrética do sistema religioso que se desenvolveu na Amazônia, uma explicação é válida sobre o termo sincretismo. O vocábulo, segundo Abbagnano, foi empregado em "história das religiões para indicar os fenômenos de sobreposição e fusão de crenças de origens diversas. Neste caso, o termo também é usado com disposição polêmica para designar sínteses mal feitas, não tendo, portanto, significado preciso"83. E como é possível constatar, a partir desta definição, é que o termo é geralmente tomado como sinônimo de "sínteses mal feitas", dando-se especial atenção esta última expressão ("mal feitas").

Acontece, porém, que é praticamente impossível falar de religião sem falar de sincretismo. E é também comum observar que muito do que é tomado por uma religião a partir de outras religiões e sistemas passam a funcionar, conquanto com algum grau de conflito no início, de maneira perfeitamente orgânica e integrada naquela que emprestou. De acordo com Eliade, por exemplo, pais da igreja cristã "cristianizaram os símbolos, os ritos e os mitos asiânicos e mediterrâneos, relacionando-os a uma 'história

\footnotetext{
80 JACOB, 1968, p. 243.

81 LOURO; SOUZA, 2014, p. 143.

82 GALVÃO, 1955, p. 43.

${ }^{83}$ ABBAGNANO, Nicola. Dicionário de filosofia. Trad. Alfredo Bosi e Ivone Castilho. 5 ed. São Paulo: Martins Fontes, 2007, p. 903.
}

Revista Pax Domini | Faculdade Boas Novas | v. 3 | p. 117 - 142 | ago. 2018 
sacra"', assim como, mais tarde, na Europa Central e Ocidental, "acabaram por 'cristianizar' as Figuras divinas e os mitos 'pagãos' que resistiam à extirpação" ${ }^{44}$. De forma semelhante, quando na Amazônia o sacerdote cristão, na busca por "atrair o catecúmeno gentio", transformou "Deus em Tupã e o diabo em Jurupari”, isso não deixou de ser um sincretismo ${ }^{85}$. Weber da mesma forma, disse que ao olharmos para a Ásia, "observamos aquela justaposição de cultos, doutrinas, seitas e ordens de todo tipo que também era própria da Antiguidade ocidental" 86 . Citam-se, aqui, esses exemplos, mas eles, certamente, poderiam continuar ad infinitum.

Logo, é possível afirmar, cum grano salis, que o sincretismo, em se tratando de religião, é um fenômeno relativamente comum, até esperado, e não deveria, talvez, ser visto de forma tão enfática como "sínteses mal feitas", como se costuma pensar. Até porque, em certo nível, uma religião pode ser tomada como uma "formação discursiva" e esta "não é um espaço estruturalmente fechado, pois é constitutivamente 'invadido' por elementos que vêm de outro lugar" ${ }^{\prime 3}$. Cada tempo ou época impõe seu desafio às religiões.

Mas, passando agora a analisar o excerto que foi colocado acima no texto, chamo a atenção para a maneira clara como nele aparecem juntos o cristianismo e a mitologia amazoníndia, os dois sistemas que serviram de base para o sistema religioso que viria a se instalar na Amazônia. De um lado têm-se as figuras cristãs, representadas por "Nossa Senhora" e por "Cristo". Poderíamos ainda incluir, aqui, "diabo" (gr. diabolos) e "inferno", como vocábulos, não diria oriundos, mas que se apresentam eminentemente na literatura de cunho cristão. E de outro lado, o "Curupira" (do tupi, kurupira), a entidade mítica da tradição indígena.

Nestes outros excertos vê-se que aparece principalmente o cristianismo, como a religião que foi imposta à região e tornada, portanto, oficial: "Nossa Senhora me dê salvação, me deixe acabar perto dos filhos, em casa, nas aproximações [...]. Se é coisa

\footnotetext{
${ }^{84}$ ELIADE, 1972, p. 120.

${ }^{85}$ BENCHIMOL, Samuel. Amazônia: Formação Social e Cultural. Manaus: Editora Valer, 1999, p. 65.

${ }^{86}$ WEBER, 2003, p. 143.

${ }^{87}$ FERNANDES, Cleudemar Alves. Análise do Discurso: reflexões introdutórias. 2 ed. São Carlos: Claraluz, 2008, p. 41.
}

Revista Pax Domini | Faculdade Boas Novas | v. 3 | p. 117 - 142 | ago. 2018 
do outro mundo, rezo pro descanso da alma [...]. Domingo também se como, domingo também se come"88.

A tônica dada no romance à religião do colonizador, como pode ser visto nestes trechos, é sintomática, e talvez se justifica pelo fato de ela ter sido a estrutura sobre a qual se formou esse sistema religioso. Invocando o pensamento de Galvão "o sistema religioso que se desenvolveu como parte dessa cultura em formação tece seus elementos básicos no catolicismo ibérico do século XVI, acrescidos de outros, indígenas, principalmente tupis, modificados em sua amalgamação e desenvolvimento particulares"89.

Antes da chegado do europeu à Amazônia, trazendo o cristianismo, já reinava na região, e mesmo em nível de Brasil, uma espécie de sincretismo religioso indígena, formado pela "mitologia, politeísmo e animismo embrionário"90. Com a chegada dele, os dois sistemas religiosos se encontraram: o supernaturalismo ameríndio e o cristianismo. Como pontua Garcia, "a espada não foi a única força europeia que conquistou a Amazônia para os portugueses. O crucifixo veio estampado em suas velas; a cruz e a coroa desceram juntas o rio Amazonas"91.

Na prática, o sincretismo foi posto em ação com sacerdote cristão, que esperava que o primitivo passasse - de um salto - do politeísmo ao monoteísmo ${ }^{92}$. Sempre por meio de uma boa língua geral, o jesuíta tentou atrair o catecúmeno indígena para a sua religião, transformando sobrenaturais Tupis (Tupã e Jurupari) em divindades cristãs (Deus e Diabo), como declara Benchimol (1999, p. 65). Embora, talvez, o europeu pensasse que a catequização estava ocorrendo de forma unilateral, a influência, na verdade estava sendo recíproca, mesmo que ela tenha sido "predominantemente orientada por ideias e por instituições lusas" (Galvão, 1955, p. 9). Pois, para catequizar o índio, o jesuíta teve que se utilizar de uma boa língua geral, e para levá-lo a adorar,

\footnotetext{
88 JACOB, 1968, p. 65, 150, 248.

89 GALVÃO, 1955, p. 9.

${ }^{90}$ ARAÚJO, 2003, p. 158.

${ }^{91}$ GARCIA, Etelvina. O Amazonas em três momentos: colônia, império e república. 2 ed. Manaus: Norma Editora, 2010, p. 23.

${ }^{92}$ BATISTA, 2007, p. 55.
}

Revista Pax Domini | Faculdade Boas Novas | v. 3 | p. 117 - 142 | ago. 2018 
lançar mão de seus cantos. "A transformação dos cantos do sairé em canto de devoção cristã ilustra o que aconteceu" (Nogueira, 2008, p. 38).

Outra discussão que também pode ser feita, tendo em vista o comportamento de Luis Chato em clamar por "todos os santos", é o da mistura entre o sagrado e o profano ${ }^{93}$. Neste outro excerto, situado à página 114, essa ideia pode ser vista de forma muito clara, no momento em que ele situa lado a lado, na busca por auxílio, "Deus do céu" e o "Curupira" ou "pretinho": "rezar um Padre-Nosso, que voltar nunca mais. Rezando e chorando, meu Deus do céu! Prometer alguma coisa para o Curupira, com toda fé, a modo o pretinho se alegrar". Como é possível perceber, aqui são colocados no mesmo patamar de igualdade o Deus judaico-cristão e a entidade mitológica indígena.

Em Santos e visagens, Galvão observou que na forma de catolicismo praticada na zona rural amazônica "elementos sagrados e profanos se misturam" ${ }^{44}$. No entanto, nesse sistema religioso - em especial, no catolicismo popular — o próprio caráter do que seria profano é discutível, uma vez que as crenças não são vistas como excludentes ou "incompatíveis"95. Eliade ressalta que, dentre as religiões, o judaísmo herdou a "concepção paleoriental do Templo como cópia de um arquétipo celeste", mas que "a experiência profana, ao contrário, mantém a homogeneidade e portanto a relatividade do espaço" 96 . Com relação à Amazônia, o próprio Galvão reconhece que "embora as crenças e instituições religiosas católicas e as de origem ameríndia sirvam a objetivos diferentes, elas se completam como partes integrantes de um mesmo sistema religioso. $\mathrm{O}$ caboclo das freguesias não as distingue como forças opostas" ${ }^{97}$.

\section{Paulo Jacob: entre a Torá e o sincretismo religioso na Amazônia}

Paulo Jacob, autor do romance Chuva branca, foi descendente de judeus sefarditas transferidos para a Amazônia ${ }^{98}$. Mesmo de tradição monoteísta, como são os

\footnotetext{
93 JACOB, 1968, p. 118.

94 GALVÃO, 1955, p. 39.

${ }^{95}$ MAUÉS, 2002, p. 53.

${ }^{96}$ ELIADE, 1992, p. 34.

97 GALVÃO, 1955 , p. 7.

${ }^{98}$ BENCHIMOL, 1999, p. 78.
}

Revista Pax Domini | Faculdade Boas Novas | v. 3 | p. 117 - 142 | ago. 2018 
judeus, não deixou de registrar e de absorver, em mais de uma dúzia de romances escritos, os aspectos que marcam o sistema religioso na Amazônia.

Seus romances, em especial Chuva branca, estão infiltrados por essa maneira de a Amazônia encarar e viver o sagrado. Suas personagens retratadas, na maior parte das vezes o típico homem amazônico, por quem demonstra especial predileção, figuram infiltradas pela religiosidade que marca o tom da região: a mistura de crenças cristãs com práticas oriundas da tradição ameríndia. Aqui e acolá, para sincretizar ainda mais esse sistema religiosa, insere uma personagem hebreia, tal como faz com Salomão, que aparece nos romances O gaiola tirante rumo do rio da borracha (1987), Um pedaço de lua caía na mata (1990) e também Chuva branca. Em Um pedaço de lua caía na mata, por exemplo, ele apresenta um outro enfoque, o do judeu "que vive na Amazônia e luta diariamente para conciliar sua crença e suas tradições com a realidade do lugar" 99.

Mas, o clímax da tolerância religiosa é alcançada mesmo quando, nesse mosaico religioso que é a Amazônia, ele insere - ao lado do cristão, do judeu e do índio - outro médio-oriental ou, como ele mesmo diz, os "pioneiros fenícios da integração da Amazônia": o sírio-libanês. Isso ele o faz no romance Vila rica das queimadas (1976). Ele é, pois, o judeu sefardita "que soube amar a Torá, ao mesmo tempo em que soube atingir o zênite da tolerância religiosa" (Souza, 2015, p. 13) ao retratar uma Amazônia sincrética e pluralmente religiosa como ele verdadeiramente é.

\section{Considerações finais}

Sendo uma das portas de entrada para o conhecimento da Amazônia por meio do romance de ficção, Chuva branca permite-nos olhar para o sistema religioso que nela se formou. Por meio de sua principal personagem, o narrador Luis Chato, e também o representante coletivo dessa cultura, é projetado diante dos olhos do leitor a maneira como o homem daquilo que aqui chamei de Terceira Amazônia encara e vive o sagrado.

Ele, geralmente se identifica como católico, a religião oficial, imposta pelo colonizador, mas amalgama nesta mesma fé práticas oriundas do sistema religioso

${ }^{99}$ SOUZA, 2015, p. 6.

Revista Pax Domini | Faculdade Boas Novas | v. 3 | p. 117 - 142 | ago. 2018 
ameríndio que, ao final, pelo menos no catolicismo popular, não se mostram incompatíveis, mas complementares. Chuva branca permite observar que a catequização, ao contrário do que pode ter pensado o europeu, não foi unilateral, pois o primitivo não deu um salto do politeísmo e animismo para o monoteísmo. Ao contrário, ele próprio, o sacerdote cristão, no processo, foi influenciado. A maneira como esse homem encara e vive a religião se mostra larga como é o espaço em que ele está inserido. Luis Chato mostra-se um homem que clama a todos os Santos, deuses ou entidades míticas que, porventura, podem lhe auxiliá-lo, mas que acaba, ao final, não permanecendo fiel nem cumprindo suas promessas a nenhuma delas.

\section{Referências}

ABBAGNANO, Nicola. Dicionário de filosofia. Trad. Alfredo Bosi e Ivone Castilho. 5 ed. São Paulo: Martins Fontes, 2007.

ALCORÃO. Português. Alcorão. Trad. Mansour Challita. Rio de Janeiro: Associação Cultural Internacional Gibran, 1995.

ARAÚJO, André Vidal de. Introdução à Sociologia da Amazônia. 2 ed. revista. Manaus: Editora Valer/Governo do Estado do Amazonas/Editora da Universidade Federal do Amazonas, 2003.

BATAILLE, Georges. Teoria da religião. Trad. Sérgio Goes de Paula e Viviane de Lamare. São Paulo: Ática, 1993.

BATISTA, Djalma. O complexo da Amazônia: análise do processo de desenvolvimento. 2 ed. Manaus: Editora Valer, Edua e Inpa, 2007.

BENCHIMOL, Samuel. Amazônia: Formação Social e Cultural. Manaus: Editora Valer, 1999.

BOSI, Alfredo. Dialética da colonização. São Paulo: Companhia das Letras, 1992.

CASSIRER, Ernst. Linguagem e mito. 3 ed. Trad. J. Guinsburg e Míriam Schnaiderman. São Paulo: Perspectiva, 1992.

DURKHEIM, Emile. As formas elementares da vida religiosa. In: TEIXEIRA, Faustino (org.): Sociologia da Religião: Enfoques teóricos. Petrópolis: Vozes, 2003, pp. 36-66.

Revista Pax Domini | Faculdade Boas Novas | v. 3 | p. 117 - 142 | ago. 2018 
ELIADE, Mircea. Mito e realidade. Trad. Pola Civelli. São Paulo: Editora Perspectiva, 1972.

Fontes, 1992.

O sagrado e o profano. Trad. Rogério Fernandes. São Paulo: Martins

FERNANDES, Cleudemar Alves. Análise do Discurso: reflexões introdutórias. 2 ed. São Carlos: Claraluz, 2008.

GALVÃO, Eduardo. Santos e visagens: um estudo da vida religiosa de Itá, Baixo Amazonas. São Paulo: Companhia Editora Nacional, 1955.

GARCIA, Etelvina. O Amazonas em três momentos: colônia, império e república. 2 ed. Manaus: Norma Editora, 2010.

GEERTZ, Clifford. A interpretação das culturas. Rio de Janeiro: LTC, 2008.

GONZÁLEZ, Justo L. E até aos confins da Terra: uma história ilustrada do Cristianismo. Trad. Key Yuasa. São Paulo: Vida Nova, 1995.

HEGEL, Georg Wilhelme Friedrich. Princípios da filosofia do direito. Trad. Orlando Vitorino. São Paulo: Martins Fontes, 1997.

HOLANDA, Sérgio Buarque de. Raízes do Brasil. 26 ed. São Paulo: Companhia das Letras, 1995.

HUGH-JONES, Stephen. Nomes secretos e riqueza visível: nominação no noroeste Amazônico. Mana, vol.8, no.2, Rio de Janeiro, Oct. 2002.

HUME, David. Diálogos sobre a religião natural. Trad. José Oscar de Almeida Outra Amazônia Marques. São Paulo: Martins Fontes, 1992.

JOUVE, Vincent. A leitura. Trad. Brigitte Hervot. São Paulo: Editora UNESP, 2002.

LIVINGSTONE, George Herbert et al. Comentário bíblico Beacon: Gênesis a Deuteronômio. Trad. Luís Aron de Macedo. Rio de Janeiro: CPAD, 2005.

LOURO, Francisca de Lourdes Souza. A significação social na Amazônia no romance Chuva Branca de Paulo Jacob. Novum Millenium, Manaus, v. 5, p. 72-78, 2007.

MAUÉS, Raymundo Heraldo. A Mãe e o Filho como peregrinos: dois modelos de peregrinação católica no Brasil. Religião e Sociedade, Rio de Janeiro, 33(2): 121-140, 2013.

Revista Pax Domini | Faculdade Boas Novas | v. 3 | p. 117 - 142 | ago. 2018 
. Catolicismo e xamanismo: comparação entre a cura no Movimento Carismático e na pajelança rural amazônica. ILHA - Florianópolis, v.4, n.2, dezembro de 2002, p. 51-77.

.Os santos e o catolicismo popular. Norte Ciência, vol. 2, n. 1, p. 1-26 (2011).

. Um aspecto da diversidade cultural do caboclo amazônico: a religião. Estud. Av. vol. 19, n. 53, São Paulo, jan./apr. 2005.

MAUSS, Marcel; HUBERT, Henri. Sobre o sacrifício. São Paulo: Cosac Naify, 2005.

MENEZES, Renata de Castro. Celebrando São Besso ou o que Robert Hertz e a Escola Francesa de Sociologia têm a nos dizer sobre festas, rituais e simbolismo. Religião e Sociedade, Rio de Janeiro, 29(1): 179-199, 2009.

MONTESQUIEU, Charles de Secondat, Baron de. O espírito das leis. Trad. Cristina Murachco. São Paulo: Martins Fontes, 1996.

NOGUEIRA, Wilson. Festas Amazônicas - boi-bumbá, ciranda e sairé. Manaus: Editora Valer, 2008.

OTTO, Rudolf. O sagrado: os aspectos irracionais na noção do divino e sua relação com o racional. 3 ed. Trad. Walter O. Schlupp. São Leopoldo: Sinodal/EST; Petrópolis: Vozes, 2007.

PANTOJA, Vanda. Santos e Espírito Santo, ou católicos e evangélicos na Amazônia Marajoara. Tese (Doutorado) - Universidade Federal do Pará. Instituto de Filosofia e Ciências Humanas, Programa de Pós-Graduação em Ciências Sociais, Belém, 2011.

PLATÃO. A República. Trad. Enrico Corvisieri. São Paulo: Editora Nova Cultural, 1997.

RATZINGER, Joseph. Introdução ao cristianismo: preleções sobre o símbolo apostólico. Trad. Pe. José Wisniewski Filho. São Paulo: Editora Herder, 1970.

RIGONI, Ana Carolina Capellini. Os usos do corpo: dos sacrifícios 'primitivos' às religiões atuais. Revista da Faculdade de Educação Física da UNICAMP, no 1: 86-96, 2008.

SANTOS, Francisco Jorge dos. História do Amazonas: 1 série, ensino médio. Rio de Janeiro: MEMVAVMEM, 2010.

SOUZA, Jamescley Almeida. Paulo Jacob: uma fortuna crítica. O Guari (União da Vitória), n. 1, v. 1, 2015.

Revista Pax Domini | Faculdade Boas Novas | v. 3 | p. 117 - 142 | ago. 2018 
LOURO, Francisca de Lourdes Souza; SOUZA, Jamescley Almeida. Chuva Branca: o retrato cultural da sociedade amazônica brasileira na obra de Paulo Jacob. Revista Decifrar, v. 02, p. 135-151, 2014.

TUVERI, Giovanni Battista. Hermenêutica e linguagens da religião no contexto amazônico: estudos da religião a partir das obras de Raymundo Heraldo Maués. 146 f. Dissertação (Mestrado em Ciências da Religião). Universidade do Estado do Pará, Belém, 2013.

VERÍSSIMO, José. Estudos Amazônicos. Belém: Universidade Federal do Pará, 1970. WEBER, Max. Sociologia. 7 ed. São Paulo: Ática, 2003. 